\title{
Child Abuse or Bleeding Disorder-An Interdisciplinary Approach
}

\author{
${ }^{1}$ Department of Pediatric Hemostaseology, Medical Faculty Carl \\ Gustav Carus, Technical University Dresden, Children's Hospital, \\ Dresden, Sachsen, Germany \\ 2 Department of Pediatrics, Medical University of Innsbruck, \\ Innsbruck, Tirol, Austria \\ ${ }^{3}$ Department of Pediatric Radiology, Medical Faculty Carl Gustav \\ Carus, Technical University Dresden, Dresden, Sachsen, Germany \\ 4 Institute of Forensic Medicine, Medical Faculty Carl Gustav Carus, \\ Technical University Dresden, Dresden, Sachsen, Germany \\ Hämostaseologie 2019;39:28-35.
}

Ralf Knöfler ${ }^{1}$ Werner Streif ${ }^{2}$ Irmina Watzer-Herberth ${ }^{1}$ Gabriele Hahn ${ }^{3}$ Uwe Schmidt ${ }^{4}$ Address for correspondence Prof. Dr. med. Ralf Knöfler, Department
of Pediatric Hemostaseology, Medical Faculty of Technical University
Dresden, Fetscherstr. 74, Dresden, Sachsen 01307, Germany
(e-mail: ralf.knoefler@uniklinikum-dresden.de).

\begin{abstract}
Keywords

- child abuse

- injuries

- bleeding symptoms

- haemostasis testing

Children with an unexplained bleeding tendency are frequently referred to a haemostaseologist for further evaluation. Careful standardized history taking and clinical evaluation should allow for distinguishing bleeds after minor injury and trauma which are very common in all children. However, in two groups of children bleeding symptoms may be more significant than expected: those with an underlying coagulation disorder and those who have been subjected to physical child abuse. The coexistence of child abuse and a bleeding disorder must always be considered. An extended coagulation diagnostic is required if the morphology of bleedings is not clearly suspicious for child abuse and in the absence of typical concomitant injuries, e.g., bone fractures. An interdisciplinary approach involving a forensic pathologist and a paediatric haemostaseologist for assessment of bleeding symptoms, the explanation of the clinical findings, and the critical evaluation of laboratory results are essential in such cases. This review is focussed on symptoms in accidental and nonaccidental injuries in children assisting haemostaseologists in decision making in cases of child protection issues.
\end{abstract}

Zusammenfassung

Schlüsselwörter

- Kindesmisshandlung

- Verletzungen

- Blutungssymptome

- Gerinnungsdiagnostik

Kinder mit unklarer Blutungsneigung werden häufig zum Hämostaseologen zur Abklärung geschickt. Eine standardisierte Ananmneseerhebung und klinische Untersuchung erlauben es zu entscheiden, ob es sich um Blutungen durch kleine Verletzungen und Traumata handelt. In der Regel treten bei 2 Gruppen von Kindern relevante Blutungen auf: Kinder mit Gerinnungsstörung und solche, die körperlich misshandelt werden. Dabei ist stets zu berücksichtigen, dass auch gleichzeitig eine Gerinnungsstörung und eine Misshandlung vorliegen kann. Eine erweiterte Gerinnungsdiagnostik ist erforderlich, wenn die Blutungsmorphe nicht eindeutig für eine Misshandlung spricht und beim Fehlen typischer Begleitverletzungen, wie Frakturen. In diesen Fällen ist ein interdisziplinäres Vorgehen unter Einbeziehung eines Rechtsmediziners und eines pädiatrischen Hämostaseologen zur Beurteilung der Symptome, den Erklärungen für das vorliegende klinische Bild und eine kritische Bewertung der Befunde der Gerinnungsdiagnostik notwendig. Diese Übersichtsarbeit fokussiert auf Symptome bei akzidentellen und nicht-akzidentellen Verletzungen und soll eine Entscheidungshilfe für Hämostaseologen in Kinderschutzfällen darstellen. received

October 9, 2018

accepted after revision

November 21, 2018 (c) 2019 Georg Thieme Verlag KG Stuttgart · New York
DOI https://doi.org/

10.1055/s-0039-1677714. ISSN 0720-9355. 


\section{Introduction}

The most easily recognizable physical signs of child abuse are seen in the skin and are often manifest as bruises. ${ }^{1,2} \mathrm{Al}-$ though the detection of abuse is vital, the physicians involved in such cases face the problems of potential alternative diagnoses when confronted with injuries that are suspected of being nonaccidental. It may be difficult to distinguish abuse from other diseases and conditions that produce similar signs and symptoms. Clearly, part of the diagnostic algorithms must involve the identification and diagnosis of an underlying coagulation disorder. It must be clear that abnormal findings in the coagulation tests do not necessarily exclude abuse. Therefore, knowledge of symptoms in accidental and nonaccidental injuries is essential also for any physician in such cases.

\section{Injuries}

In case of relevant physical injuries in children, the plausibility of the given explanations by caregivers must be critically checked, considering the child's age, history, and level of activity (-Table 1). For instance, the onset of bleeding symptoms in infants younger than 1 year of age is extremely rare and such findings may therefore point towards nonaccidental injury or a severe form of a coagulation disorder.

\section{Skin and Soft-Tissue Bleedings}

Because skin and soft-tissue bleedings are major findings in child abuse, their precise assessment and documentation are crucial for the investigations of suspicious cases (- Tables 2 and 3). It is essential to consider the age-dependent mobility of the child. Small and locally limited haematomas are frequently observed in children starting at the end of the first year of life due to the progressive motor development and the increased incidence of minor traumas. These soft-tissue bleedings are typically located in prominent areas of the body such as in the area of the forehead, pretibial, elbow, and back of head. As shown in -Fig. 1, atypical bleedings on the other hand are localized on the chest, back, neck, genitals, the dorsal sides of thighs, and the forearms. ${ }^{1,5}$ Petechial bleedings occur more frequently in cases of child abuse than in accidental injuries. ${ }^{6}$

As depicted in -Table 3, the presence of the rare EhlersDanlos syndrome as a heterogeneous group of connectivetissue disorders should also be considered as the reason for easy bruising.

\section{Intracranial Haemorrhage}

The incidence of nonaccidental head injuries depends on age whereby mainly children of less than 3 years of age with a peak between 2 and 5 months are affected. Based on the high lethality ranging from 30 to $70 \%$, this form of child abuse is

Table 1 Validity of physical injuries for the presence of child abuse (modified according to Herrmann $2002^{3}$ and Sorantin and Lindbichler ${ }^{4}$ )

\begin{tabular}{|c|c|}
\hline \multicolumn{2}{|c|}{ Physical injuries of high significance for child abuse } \\
\hline $\begin{array}{l}\text { Central nervous } \\
\text { system (CNS) }\end{array}$ & $\begin{array}{l}\text { - Subdural haematomas in combination with retinal bleeding and neurologic symptoms } \\
\text { - Retinal bleeding } \\
\text { - Retinoschisis } \\
\text { - Vitreous body bleeding }\end{array}$ \\
\hline Abdomen & $\begin{array}{l}\text { - Intramural duodenal haematoma } \\
\text { - Hollow organ perforations }\end{array}$ \\
\hline Fractures & $\begin{array}{l}\text { - Classical metaphyseal bone fracture (children }<2 \text { years) } \\
\text { - Rib fractures } \\
\text { - Fractures of scapula, processus spinosus, or/and sternum } \\
\text { - Fracture(s) within the first } 6 \text { months of life (premobile infants) without adequate history }\end{array}$ \\
\hline \multicolumn{2}{|c|}{ Physical injuries of moderate significance for child abuse } \\
\hline CNS & - Subdural haematomas (particularly over the convexity, interhemispherial, and subarachnoidal) \\
\hline Abdomen & - Injuries of left liver lobe and/or kidneys and/or pancreas, pancreas pseudocysts \\
\hline Throat-nose-ears & - Hypopharynx perforations \\
\hline Fractures & $\begin{array}{l}\text { - Multiple, particularly both-sided fractures } \\
\text { - Fractures of various ages } \\
\text { - Epiphysiolysis } \\
\text { - Vertebral body fractures } \\
\text { - Fractures on fingers, hands, and feet } \\
\text { - Complex skull fractures (particularly with accompanied intracranial injuries) } \\
\text { - Mandible fractures } \\
\text { - Periosteum alterations } \\
\text { - Fractures in infants }\end{array}$ \\
\hline other & - Relapsed apnoea (apparent life-threatening event) \\
\hline
\end{tabular}


Table 2 Specificity of skin and soft-tissue bleedings in child abuse (modified according to Herrmann 2002 ${ }^{3}$ )

\begin{tabular}{|l|l|}
\hline High specificity & $\begin{array}{l}\text { - Patterned haematomas (e.g., grip marks, finger marks, welts, belt, loops, and sticks); } \\
\text { see also } \\
\text { - Bite marks - Fig. } 2\end{array}$ \\
\hline Moderate specificity & $\begin{array}{l}\text { - Multiple haematomas } \\
\text { - Unusual haematoma sites such as face, retroauricular, abdomen, buttocks, } \\
\text { arms, and hands } \\
\text { - Haematoma in infants }\end{array}$ \\
\hline Low specificity & $\begin{array}{l}\text { Multiple haematomas in mobile toddlers on prominent parts of body; } \\
\text { see also - Fig. } 3\end{array}$ \\
& Different coloured haematomas \\
\hline
\end{tabular}

Table 3 Differential diagnoses of skin and soft-tissue bleedings (modified according to Jaffe $1994^{7}$ and Herrmann et al $2010^{8}$ )

\begin{tabular}{|c|c|c|}
\hline \multirow[t]{4}{*}{ Haematoma } & Accidental haematoma & Preferentially on bony prominences (“leading edges“) \\
\hline & Coagulation disorders & $\begin{array}{l}\text { For example, coagulation factor deficiencies such as haemophilia, } \\
\text { von Willebrand syndrome (VWS), } \\
\text { thrombocytopenia and -pathy, vitamin K deficiency, } \\
\text { accidental anticoagulant intake }\end{array}$ \\
\hline & $\begin{array}{l}\text { Congenital disorders } \\
\text { and skin variations }\end{array}$ & $\begin{array}{l}\text { Mongolian spot, } \\
\text { Ehlers--Danlos syndrome }\end{array}$ \\
\hline & Infections & Erythema multiforme \\
\hline Purpura & Vasopathies & e.g., Schönlein-Henoch purpura \\
\hline \multirow[t]{6}{*}{ Petechiae } & $\begin{array}{l}\text { Increased pressure in } \\
\text { the regions of head, } \\
\text { neck, or thorax }\end{array}$ & Vomiting, cough attacks, excessive crying \\
\hline & Accidents/violence & $\begin{array}{l}\text { Near-drowning, incarcerations, electrical accidents, } \\
\text { foreign body aspiration, } \\
\text { compression of neck soft tissue (crapping, choking) }\end{array}$ \\
\hline & Coagulation disorders & $\begin{array}{l}\text { Thrombocytopenia and -pathy, VWS, sepsis with disseminated } \\
\text { intravascular coagulation (DIC) }\end{array}$ \\
\hline & Vasopathies & e.g., Schönlein-Henoch purpura \\
\hline & Intoxications & e.g., Colchicine intoxication \\
\hline & Others & Complicated spontaneous delivery, after cardiopulmonary reanimation \\
\hline
\end{tabular}

the most common nonnatural cause of death in infants and toddlers. ${ }^{9,10}$ Intracranial injuries with bleedings are due to a direct force effect as a result of blows or of kicks with clashing the skull on a tight surface and or by an indirect force effect mostly referred as "shaken baby syndrome."

One distinguishes between epidural, subdural, subarachnoidal, and intraparenchymatous bleedings. The subdural haematoma originates mainly from trauma by tearing of bridging veins with consecutive bleeding between dura mater and arachnoidea. It occurs more frequently in the cases of nonaccidental injuries. The appearance of a subdural haematoma is more suspicious for child abuse compared with the epidural haematoma which is the consequence of an arterial bleeding and located between dura and cranium. ${ }^{11,12}$ Following drops of minor height no clinically relevant injuries including an intracranial haemorrhage (ICH) are expected..$^{13}$ Brain lesions are often accompanied by a subarachnoidal bleeding which often occurs in cases of child abuse.

The shaken baby syndrome represents a common form of nonaccidental craniocerebral injury in newborns and infants. It is associated with significant clinical consequences including retarded neurological development and tendency to seizures. It requires a massive bouncing back and forth shaking of the child who is kept tightly on the upper arms or the trunk. ${ }^{14}$ The mechanism of the forcible shaking leads to an uncontrolled head rotation and serious sheer forces in different intracranial compartments. This results in diffuse cerebral parenchyma damages and typically in the bilateral or the interhemisphere gap located subdural bleedings (see also - Fig. 4). ${ }^{14,15}$

Pronounced retinal bleedings are highly suspicious for child abuse, especially for the act of shaking. ${ }^{16,17}$

Intracranial bleedings may also occur in rare cases of inborn errors of metabolism, e.g., in glutaric aciduria of type I. ${ }^{18-20}$ Reports for the first manifestation of Menkes syndrome with an $\mathrm{ICH}^{21}$ and retinal bleedings in galactosemia exist. ${ }^{22}$

Intracranial perinatal injuries with subdural and retinal bleeds that occur mainly in association with vacuum extraction are rarely serious ${ }^{23,24}$ and are typically completely absorbed approximately 4 weeks after delivery. ${ }^{14}$ History 


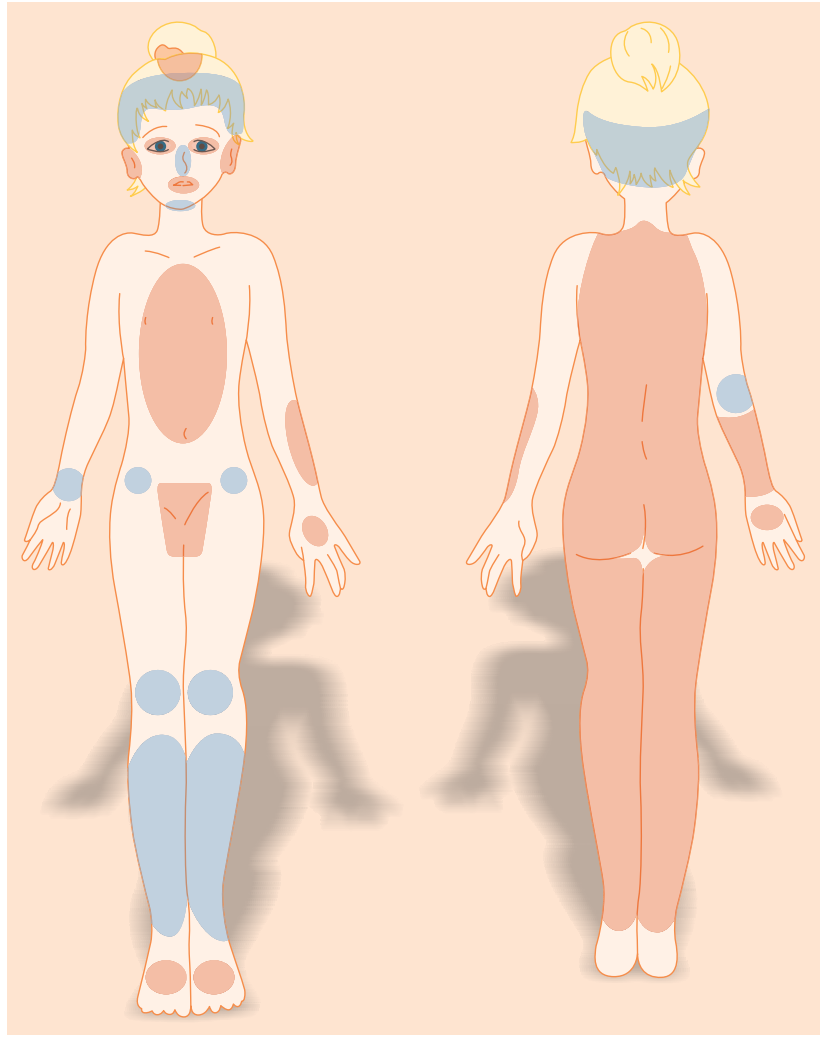

Fig. 1 Typical allocations of haematomas in injuries (in blue) and in child abuse (in red) (adapted from Knöfler et al 2014. ${ }^{37}$ )

of prolonged persistence of cutaneous haematoma and prolonged or severe jaundice may be an early symptom of inherited bleeding disorders.

Congenital bleeding disorders are a minor but a significant cause of $\mathrm{ICH}^{25}$ The risk of this life-threatening bleeding is highly variable and depends on the underlying disease. For instance, despite the typically very low platelet count of less

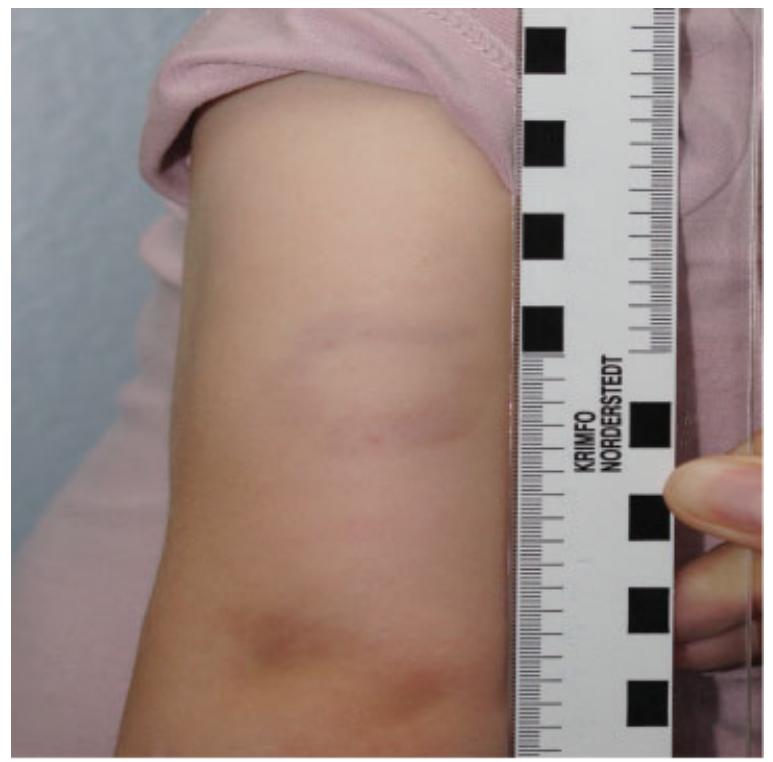

Fig. 2 Bite mark on the upper arm.

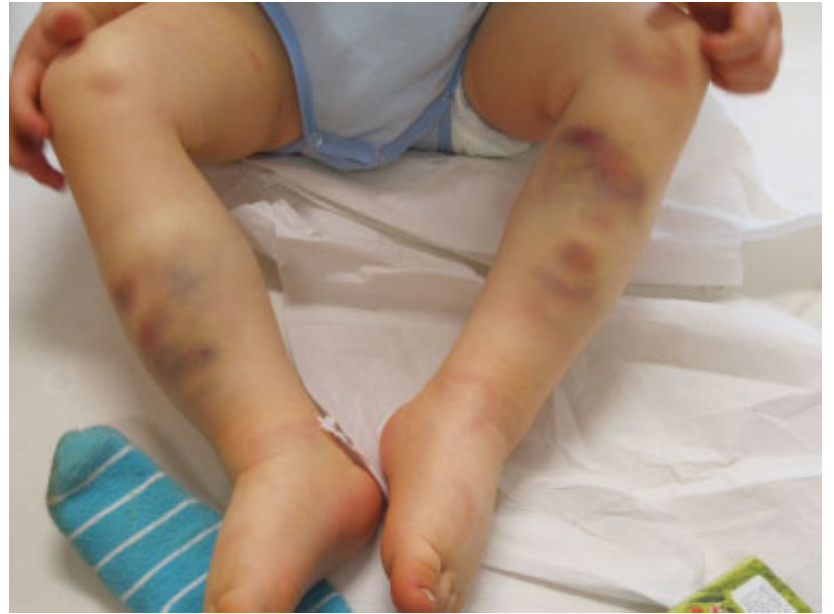

Fig. 3 Multiple pretibial haematomas in a toddler with severe haemophilia A.

than $20,000 / \mu \mathrm{L}$, the risk is less than $1 \%$ in children with immune thrombocytopenia. ${ }^{26}$ Most inherited platelet function disorders have a mild to moderate bleeding tendency that can never experience a severe bleeding such as ICH. However, Glanzmann's thrombasthenia as a very rare but severe form can lead to $\mathrm{ICH}$. Contrastingly, in patients with severe haemophilia, ICH may occur after minor trauma but

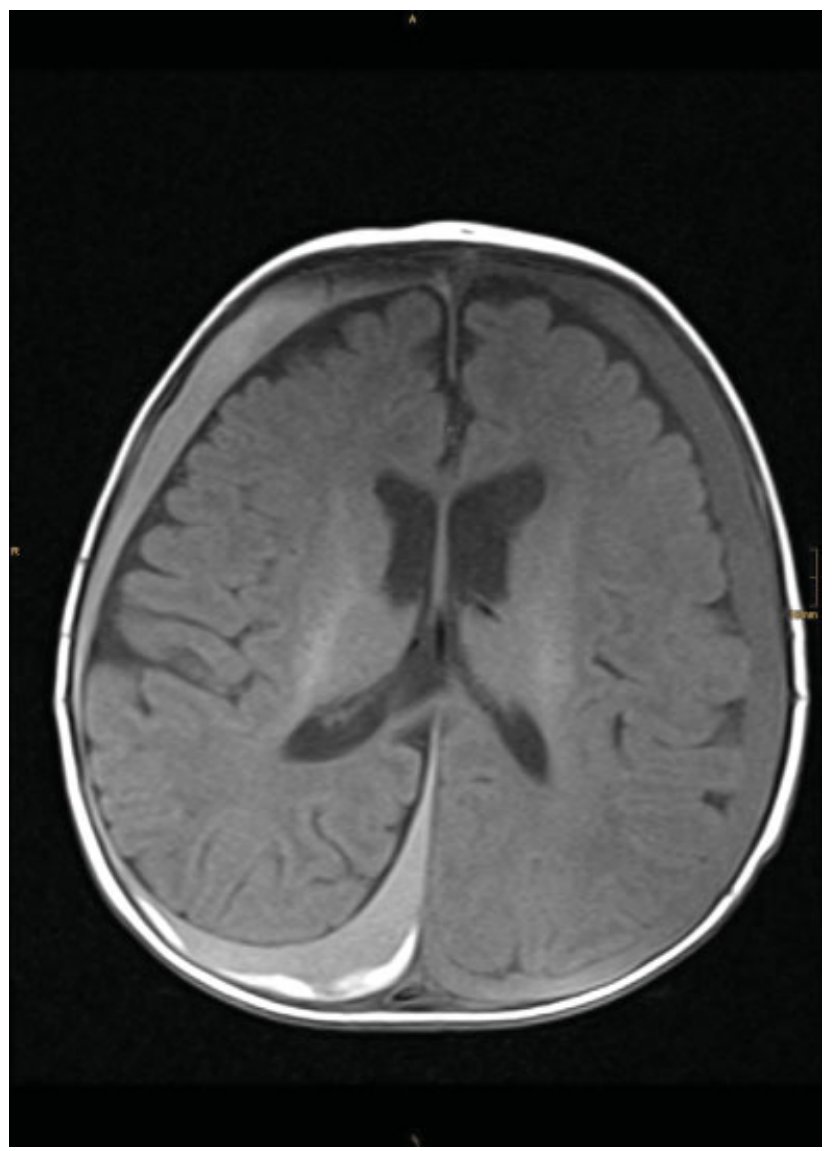

Fig. 4 Typical MRI findings in shaken baby syndrome showing bilateral subarachnoidal bleedings of different ages extended into the interhemisphere gap. MRI, magnetic resonance imaging. 
also spontaneously. ${ }^{27,28}$ More common is the ICH in patients with inherited severe factor XIII deficiency where it occurs in about one-third of these patients. ${ }^{29}$

\section{Significance of Haemostasis Testing}

An unclear bleeding tendency in childhood calls for an extended coagulation work-up, particularly if child abuse is suspected and typical concomitant injuries are absent. The chosen diagnostic tests should be able to detect the presence of relatively common coagulation defects such as von Wil- lebrand syndrome or haemophilia, but also rare diseases such as inherited thrombocytopathies. Coagulation testing in these cases should be part of an extensive diagnostic workup depicted as a checklist shown below.

Before performing coagulation testing the evaluation of a detailed bleeding history of the child and the family members is of particular importance. ${ }^{1,30}$ Standardized bleeding questionnaires (ped International Society of Thrombosis and Haemostasis - Bleeding Assessment Tool (ISTH-BAT)) are especially helpful in children beyond 1 year of age. ${ }^{31}$

Table 4 Check list for proceedings in children with bleedings suspicious for child abuse (according to Knöfler and Schmidt 2018 ) 39

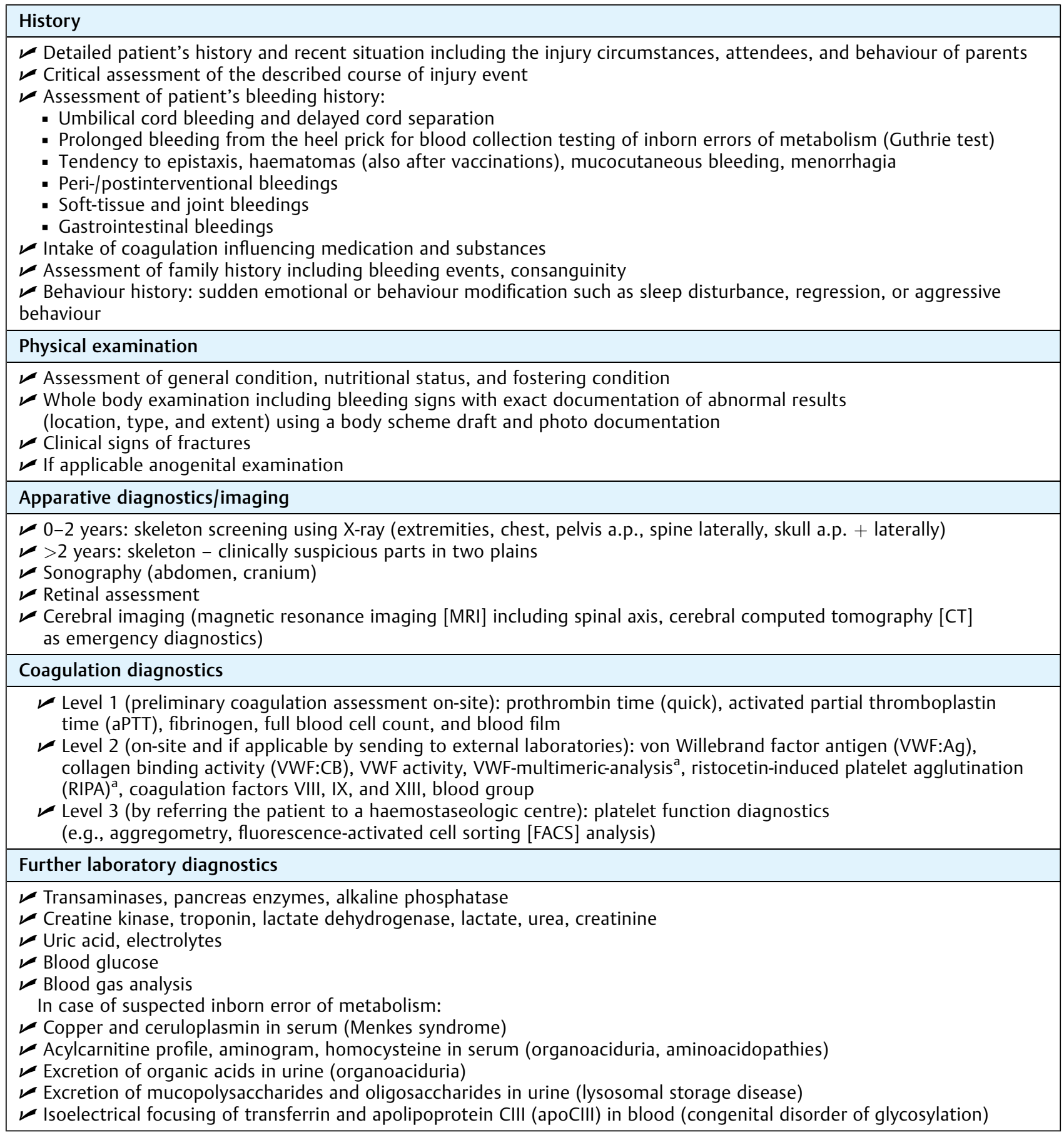

${ }^{a}$ VWF multimeric testing and RIPA only recommended if VWD type 2 suspected. 
It should be taken into consideration that the global coagulation screening tests (prothrombin time [PT] and activated partial thromboplastin time [aPTT]) and the determination of blood cell count do not rule out the presence of von Willebrand disease, factor XIII deficiency, or inherited thrombocytopathies. ${ }^{32-37}$ However, due to the lack of clear reference ranges, especially in neonates and infants, the interpretation of some individual findings of some coagulation studies can be considerably difficult for infants below 6 to 12 months of age. ${ }^{38}$ Moreover, the limited availability of coagulation tests in specialized laboratories and some preanalytical problems, such as decreased clotting factor activities due to a long sample transport to external laboratories, must also be taken into account.

Initially, coagulation diagnostics that are available on-site should be performed to implement all level 1 tests (PT, PTT, fibrinogen, and platelet counts). Level 2 coagulation tests (blood group, von Willebrand factor antigen and function, and factors VIII, IX, and XIII) cannot be done sufficiently onsite in some hospitals. Therefore, citrate plasma samples must be sent to specialized coagulation laboratories with the exception of samples for platelet function. Most platelet tests can only performed from freshly taken venous blood samples. For this reason it is highly recommended to refer patients to a centre with expertise in bleeding disorders.

We recommend the use of a check list for proceedings in children with bleedings suspicious for child abuse (Tab. 4; according to Knöfler and Schmidt 2018). ${ }^{39}$

\section{Conclusions}

Child protection is an interdisciplinary challenge. Suspicious skin bleedings may be associated with internal injuries or bone fractures. To clarify suspicious findings a child protection group consisting of paediatricians, paediatric surgeons, paediatric radiologists, forensic doctors, and social workers should discuss the diagnostic procedure together. In some cases it is necessary to involve other specialized disciplines such as ophthalmology, haemostaseology, or paediatric psychiatry. Findings should be evaluated together in a case conference.

\section{Conflict of Interest}

On behalf of all co-authors the first and the senior author declare no conflicts of interest.

\section{References}

1 Khair K, Liesner R. Bruising and bleeding in infants and children-a practical approach. Br J Haematol 2006;133(03):221-231

2 Sibert J. Bruising, coagulation disorder, and physical child abuse. Blood Coagul Fibrinolysis 2004;15(Suppl 1):S33-S39

3 Herrmann B. Körperliche Misshandlung von Kindern. Somatische Befunde und klinische Diagnostik. Monatsschr Kinderheilkd 2002;150:1324-1338

4 Sorantin E, Lindbichler F. Die nicht unfallbedingte Verletzung (battered child). Monatsschr Kinderheilkd 2002;150:1068-1075

5 Herrmann B. Hautbefunde bei Kindesmisshandlung - Machen blaue Flecken krank? Monatsschr Kinderheilkd 2005;153: 1077-1081

6 Nayak K, Spencer N, Shenoy M, Rubithon J, Coad N, Logan S. How useful is the presence of petechiae in distinguishing non-acci- dental from accidental injury? Child Abuse Negl 2006;30(05): 549-555

7 Jaffe FA. Petechial hemorrhages. A review of pathogenesis. Am J Forensic Med Pathol 1994;15(03):203-207

8 Herrmann B, Dettmeyer R, Banaschak S, Thyen U. Kindesmisshandlung. Berlin: Springer; 2010:51-71

9 Duhaime AC, Christian CW, Rorke LB, Zimmerman RA. Nonaccidental head injury in infants-the "shaken-baby syndrome". N Engl J Med 1998;338(25):1822-1829

10 Karibe H, Kameyama M, Hayashi T, Narisawa A, Tominaga T. Acute subdural hematoma in infants with abusive head trauma: a literature review. Neurol Med Chir (Tokyo) 2016;56(05):264-273

11 Reece RM, Sege R. Childhood head injuries: accidental or inflicted? Arch Pediatr Adolesc Med 2000;154(01):11-15

12 Adamo MA, Drazin D, Smith C, Waldman JB. Comparison of accidental and nonaccidental traumatic brain injuries in infants and toddlers: demographics, neurosurgical interventions, and outcomes. J Neurosurg Pediatr 2009;4(05):414-419

13 Alexander RC, Levitt CJ, Smith WL. Abusive head trauma. In: Reece RM, Ludwig S, eds. Child Abuse - Medical Diagnosis and Management. Philadelphia, PA: Lippincott Williams \& Wilkins; 2001:47-80

14 Herrmann B, Dettmeyer R, Banaschak S, Thyen U. Kindesmisshandlung - Medizinische Diagnostik, Intervention und rechtliche Grundlagen. Berlin: Springer; 2016

15 Herrmann B. Nicht akzidentelle Kopfverletzungen und Schütteltrauma. Klinische und pathophysiologische Aspekte. Rechtsmedizin 2008;18:9-16

16 Gilliland MGF, Luckenbach MW, Chenier TC. Systemic and ocular findings in 169 prospectively studied child deaths: retinal hemorrhages usually mean child abuse. Forensic Sci Int 1994;68(02): 117-132

17 Bechtel K, Stoessel K, Leventhal JM, et al. Characteristics that distinguish accidental from abusive injury in hospitalized young children with head trauma. Pediatrics 2004;114(01):165-168

18 Hartley LM, Khwaja OS, Verity CM. Glutaric aciduria type 1 and nonaccidental head injury. Pediatrics 2001;107(01):174-175

19 Gago LC, Wegner RK, Capone A Jr, Williams GA. Intraretinal hemorrhages and chronic subdural effusions: glutaric aciduria type 1 can be mistaken for shaken baby syndrome. Retina 2003;23 (05):724-726

20 Scholl-Bürgi S, Kapelari K, Michel M, Pavlic M, Streif W, Karall D. Angeborene Stoffwechselstörungen in der Differenzialdiagnose von Kindesmisshandlung. Pädiatrische Praxis 2016;86:273-283

21 Nassogne MC, Sharrard M, Hertz-Pannier L, et al. Massive subdural haematomas in Menkes disease mimicking shaken baby syndrome. Childs Nerv Syst 2002;18(12):729-731

22 Levy HL, Brown AE, Williams SE, de Juan E Jr. Vitreous hemorrhage as an ophthalmic complication of galactosemia. J Pediatr 1996; 129(06):922-925

23 Emerson MV, Pieramici DJ, Stoessel KM, Berreen JP, Gariano RF. Incidence and rate of disappearance of retinal hemorrhage in newborns. Ophthalmology 2001;108(01):36-39

24 Whitby EH, Griffiths PD, Rutter S, et al. Frequency and natural history of subdural haemorrhages in babies and relation to obstetric factors. Lancet 2004;363(9412):846-851

25 Tabibian S, Motlagh H, Naderi M, Dorgalaleh A. Intracranial hemorrhage in congenital bleeding disorders. Blood Coagul Fibrinolysis 2018;29(01):1-11

26 Psaila B, Petrovic A, Page LK, Menell J, Schonholz M, Bussel JB. Intracranial hemorrhage (ICH) in children with immune thrombocytopenia (ITP): study of 40 cases. Blood 2009;114(23):4777-4783

27 Li-McLeod J, Xiong Y, Ito L, Epstein J. The incidence and impact of intracranial hemorrhages within a hemophilia and non-hemophilia population. J Thromb Haemost 2013;11:528

28 Andersson NG, Auerswald G, Barnes C, et al. Intracranial haemorrhage in children and adolescents with severe haemophilia A or B - the impact of prophylactic treatment. Br J Haematol 2017;179 (02):298-307 
29 Karimi M, Bereczky Z, Cohan N, Muszbek L. Factor XIII deficiency. Semin Thromb Hemost 2009;35(04):426-438

30 Music I, Novak M, Acham-Roschitz B, Muntean W. Screening for haemorrhagic disorders in paediatric patients by means of a questionnaire. Hamostaseologie 2009;29(Suppl 1):S87-S89

31 Bidlingmaier C, Grote V, Budde U, Olivieri M, Kurnik K. Prospective evaluation of a pediatric bleeding questionnaire and the ISTH bleeding assessment tool in children and parents in routine clinical practice. J Thromb Haemost 2012;10(07):1335-1341

32 Bidlingmaier C, Olivieri M, Kurnik K. Hautblutungen bei Kindern Ist es eine Gerinnungsstörung? Monatsschr Kinderheilkd 2012; 160:538-544

33 Newman RS, Jalili M, Kolls BJ, Dietrich R. Factor XIII deficiency mistaken for battered child syndrome: case of "correct" test ordering negated by a commonly accepted qualitative test with limited negative predictive value. Am J Hematol 2002;71(04): $328-330$
34 Olivieri M, Kurnik K, Bidlingmaier C. Coagulation testing in the evaluation of suspected child abuse. Hamostaseologie 2009; 29:190-192

35 Knöfler R, Streif W. Strategies in clinical and laboratory diagnosis of inherited platelet function disorders in children. Transfus Med Hemother 2010;37(05):231-235

36 Streif W, Knöfler R, Eberl W. Inherited disorders of platelet function in pediatric clinical practice: a diagnostic challenge. Klin Padiatr 2010;222(03):203-208

37 Knöfler R, Lohse J, Stächele J, et al. Significance of platelet function diagnostics for clarification of suspected battered child syndrome. Hamostaseologie 2014;34(Suppl 1):S53-S56

38 Kurnik K, Bidlingmaier C, Hütker S, Olivieri M. Haemostatic disorders in children [in German]. Hamostaseologie 2016;36 (02):109-125

39 Knöfler R, Schmidt U. Gerinnungsstörung, Unfall oder Misshandlung? Stuttgart: Georg Thieme Verlag; 2018 